\title{
Amidosilylcyclopentadienyl Monoalkyl Zirconium Compounds: Evidence of a N-Assisted 1,3-Proton Shift Olefin Isomerization Mechanism
}

\author{
Cristina E. Petrisor, Enrique Gómez-Bengoa ${ }^{\dagger}$ Eva Royo, ${ }^{*}$ and Tomás Cuenca* \\ Departamento de Química Inorgánica, Facultad de Ciencias, Universidad de Alcalá, 28871 Alcalá de \\ Henares, Madrid, Spain. ${ }^{\dagger}$ Facultad de Ciencias Químicas, Universidad del País Vasco, 20018, \\ San Sebastian,Spain.E-mail: enrique.gomez@ehu.es
}

Received April 21, 2009

\begin{abstract}
New $\eta^{5}$-cyclopentadienyl- $\eta^{1}$-amido monoalkyl zirconium compounds of the type $\left[\operatorname{ZrR}\left(\eta^{5}-\right.\right.$ $\left.\left.\mathrm{C}_{5} \mathrm{H}_{4} \mathrm{SiMe}_{2}-\eta^{1}-\mathrm{N}^{\mathrm{t}} \mathrm{Bu}\right)\left(\eta^{5}-\mathrm{C}_{5} \mathrm{H}_{4} \mathrm{R}^{\prime}\right)\right]\left(\mathrm{R}=\mathrm{Me}, \mathrm{Bn} ; \mathrm{R}^{\prime}=\mathrm{H}, \mathrm{SiMe}_{3}, \mathrm{SiMe}_{2} \mathrm{CH}_{2} \mathrm{CH}=\mathrm{CH}_{2}\right)$ have been synthesized and fully characterized. Allyldimethylsilylcyclopentadienyl derivatives $\operatorname{ZrR}\left(\eta^{5}-\right.$ $\left.\mathrm{C}_{5} \mathrm{H}_{4} \mathrm{SiMe}_{2}-\eta^{1}-\mathrm{N}^{\mathrm{t}} \mathrm{Bu}\right)\left(\eta^{5}-\mathrm{C}_{5} \mathrm{H}_{4} \mathrm{SiMe}_{2} \mathrm{CH}_{2} \mathrm{CH}=\mathrm{CH}_{2}\right)$ ] isomerize the allyl fragment bound to the cyclopentadienyl ring to give the corresponding $\left[\mathrm{ZrR}\left(\eta^{5}-\mathrm{C}_{5} \mathrm{H}_{4} \mathrm{SiMe}_{2}-\eta^{1}-\mathrm{N}^{\mathrm{t}} \mathrm{Bu}\right)\left(\eta^{5}-\mathrm{C}_{5} \mathrm{H}_{4} \mathrm{Si}\right.\right.$ $\left.\left.\mathrm{Me}_{2} \mathrm{CH}=\mathrm{CHCH}_{3}\right)\right]$ compounds $(\mathrm{R}=\mathrm{Me}, \mathrm{Bn})$. Experimental as well as DFT computational studies support an isomerization mechanism based on a $\mathrm{N}$-assisted 1,3-proton shift.
\end{abstract}

Chelate $\eta^{5}$-cyclopentadienyl- $\eta^{1}$-amido group 4 metal complexes such as $\left[\mathrm{MX}\left(\eta^{5}-\mathrm{C}_{5} \mathrm{Me}_{4} \mathrm{SiMe}_{2}-\eta^{1}-\mathrm{N}^{\mathrm{t}} \mathrm{Bu}\right)\left(\eta^{5}-\mathrm{C}_{5} \mathrm{H}_{5}\right)\right]^{1}$ or $\left[\mathrm{MX}\left\{\eta^{5}-\mathrm{C}_{5} \mathrm{R}_{3}\left(\mathrm{SiMe}_{2}-\eta^{1}-\mathrm{N}^{\mathrm{t}} \mathrm{Bu}\right)_{2}\right\}\right]^{2}(\mathrm{M}=\mathrm{Ti}, \mathrm{Zr} ; \mathrm{X}=\mathrm{Cl}, \mathrm{Me}$, $\mathrm{Bn} ; \mathrm{R}=\mathrm{H}, \mathrm{Me}$ ), which do not retain an alkyl ligand in their MAO-activated form, have recently proved to be active olefin polymerization precatalysts. This finding has prompted new investigations on such catalytic systems and the possible pathways through which polymerization occurs. ${ }^{1-3}$

Within this context, well-known alkene isomerization has special relevance, as it takes place very often as a side reaction during olefin polymerization processes mediated by biscyclopentadienyl group 4 compounds, and is responsible

*Corresponding authors. E-mail: tomas.cuenca@uah.es; eva.royo@ uah.es.

(1) Jin, J. Z.; Wilson, D. R.; Chen, E. Y. X. Chem. Commun. 2002, (7), 708-709, and references therein.

(2) Cano, J.; Royo, P.; Lanfranchi, M.; Pellinghelli, M. A.; Tiripicchio, A. Angew. Chem., Int. Ed. 2001, 40 (13), 2495-2497.

(3) (a) Humphries, M. J.; Tellmann, K. P.; Gibson, V. C.; White, A. J. P.; Williams, D. J. Organometallics 2005, 24, (9), 2039-2050, and references therein. (b) Kleigrewe, N.; Steffen, W.; Blomker, T.; Kehr, G.; Frohlich, R.; Wibbeling, B.; Erker, G.; Wasilke, J. C.; Wu, G.; Bazan, G. C. J. Am. Chem. Soc. 2005, 127, (40), 13955-13968, and references therein. (c) Kooistra, T. M.; Knijnenburg, Q.; Smits, J. M. M.; Horton, A. D.; Budzelaar, P. H. M.; Gal, A. W. Angew. Chem., Int. Ed. 2001, 40, (24), 4719-4722, and references therein.

(4) (a) Tobisch, S.; Taube, R. J. Organomet Chem. 2003, 683, 181190, and references therein. (b) Brintzinger, H. H.; Fischer, D.; Mulhaupt, R.; Rieger, B.; Waymouth, R. M. Angew. Chem., Int. Ed. Engl. 1995, 34 (11), 1143-1170. (c) Burger, B. J.; Thompson, M. E.; Cotter, W. D.; Bercaw, J. E. J. Am. Chem. Soc. 1990, 112 (4), 1566-1577. (d) Chirik, P. J.; Day, M. W.; Labinger, J. A.; Bercaw, J. E. J. Am. Chem. Soc. 1999, 121 (44), 10308-10317. (e) Harney, M. B.; Keaton, R. J.; Fettinger, J. C.; Sita, L. R. J. Am. Chem. Soc. 2006, 128 (10), 34203432, and references therein. (f) Harney, M. B.; Keaton, R. J.; Sita, L. R. J. Am. Chem. Soc. 2004, 126 (14), 4536-4537. (g) Hustad, P. D.; Coates, G. W. J. Am. Chem. Soc. 2002, 124 (39), 11578-11579. (h) Keaton, R. J.; Sita, L. R. J. Am. Chem. Soc. 2002, 124 (31), 9070-9071. (i) Prosenc, M. H.; Brintzinger, H. H. Organometallics 1997, 16 (18), 3889-3894. (j) Zhang, Y. H.; Keaton, R. J.; Sita, L. R. J. Am. Chem. Soc. 2003, 125 (29), 8746-8747. for epimerization of chiral centers, stereoerrors, and the socalled chain walk of group 4 metallocenes along the alkyl polymer chain. ${ }^{4,5}$ Polymerization and isomerization share fundamental reactions in organometallic chemistry, such as olefin insertion into $\mathrm{M}-\mathrm{X}(\mathrm{X}=\mathrm{H}$, alkyl $)$ bonds and the reverse, $\beta$-X elimination from a transition metal-alkyl. Thus, elucidation of the steric and electronic factors that control $\mathrm{H}$ and alkyl insertion/elimination reactions in monoalkyl constrained geometry compounds is of paramount importance for a better understanding of the mechanisms driving their polymerization and isomerization catalytic processes.

Recently, we reported the intramolecular allyl isomerization occurring in group 4 and 6 metal hydride compounds with the allyldimethylsilyl- $\eta^{5}$-cyclopentadienyl ligand. ${ }^{6-8}$ The design of such model species, which contain cyclopentadienyl units with a hemilabile binding profile, has proven to be a useful strategy to gain insight into their olefin isomerization mechanisms. While group 6 metal compounds of formula $\left[\mathrm{MH}\left(\eta^{5}-\mathrm{C}_{5} \mathrm{R}_{4} \mathrm{SiMe}_{2} \mathrm{CH}_{2} \mathrm{CH}=\mathrm{CH}_{2}\right)(\mathrm{CO})_{3}\right]$ isomerize the intramolecular pendant allyl unit selectively to the trans-prop-1-enyl-dimethylsilyl group, ${ }^{6,8}$ the allyldimethylsilyl cyclopentadienyl $\mathrm{Zr}$ hydride compound $\left[\mathrm{ZrH}\left(\eta^{5}-\right.\right.$ $\left.\left.\mathrm{C}_{5} \mathrm{H}_{4} \mathrm{SiMe}_{2}-\eta^{1}-\mathrm{N}^{t} \mathrm{Bu}\right)\left(\eta^{5}-\mathrm{C}_{5} \mathrm{H}_{4} \mathrm{SiMe}_{2} \mathrm{CH}_{2} \mathrm{CH}=\mathrm{CH}_{2}\right)\right]$ evolves to the six-membered zirconacycle derivative $\left[\mathrm{Zr}\left(\eta^{5}\right.\right.$ $\left.\left.\mathrm{C}_{5} \mathrm{H}_{4} \mathrm{SiMe}_{2}-\eta^{1}-\mathrm{N}^{\mathrm{t}} \mathrm{Bu}\right)\left(\eta^{5}-\mathrm{C}_{5} \mathrm{H}_{4} \mathrm{SiMe}_{2} \mathrm{CH}_{2} \mathrm{CH}_{2}-\eta^{1}-\mathrm{CH}_{2}\right)\right]^{7}$ Despite these remarkable experimental differences between group 4 and 6 metal derivatives, theoretical DFT calculations support a traditional metal hydride addition-elimination mechanism for both systems. ${ }^{7,8}$

(5) Chirik, P. J.; Bercaw, J. E. Organometallics 2005, 24 (22), 54075423

(6) Royo, E.; Acebrón, S.; Mosquera, M. E. G.; Royo, P. Organometallics 2007, 26, (15), 3831-3839, and references therein.

(7) Petrisor, C. E.; Frutos, L. M.; Castaño, O.; Mosquera, M. E. G.; Royo, E.; Cuenca, T. Dalton Trans. 2008, (20), 2670-2673, and references therein.

(8) Chahboun, G.; Petrisor, C. E.; Gómez-Bengoa, E.; Royo, E.; Cuenca, T. Eur. J. Inorg. Chem. 2009, 1514-1520. 
Scheme 1
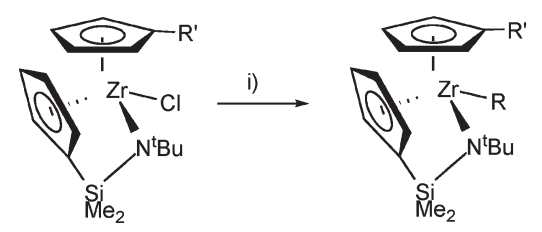

$\mathrm{R}^{\prime}=\mathrm{H}, 1$

$\mathrm{R}^{\prime}=\mathrm{SiMe}_{3}, 2$

$\mathrm{R}^{\prime}=\mathrm{H}, \mathrm{R}=\mathrm{Me}, \mathbf{4}$

$\mathrm{R}^{\prime}=\mathrm{SiMe}_{3}, \mathrm{R}=\mathrm{Me}, \mathbf{5}$

$\mathrm{R}^{\prime}=\mathrm{SiMe}_{2} \mathrm{CH}_{2} \mathrm{CH}=\mathrm{CH}_{2}, \mathrm{R}=\mathrm{Me}, 6 \mathrm{a}$

$\mathrm{R}={ }^{13} \mathrm{CH}_{3}, 6 \mathbf{a}^{*}$

i) MeLi (4-6a), ${ }^{13} \mathrm{CH}_{3} \mathrm{Li}\left(\mathbf{6 \mathbf { a } ^ { * } )}\right.$ or $\mathrm{BnMgCl}(\mathbf{7 a}) \quad \begin{array}{l}\mathrm{R}={ }^{13} \mathrm{CH}_{3}, \\ \mathrm{R}=\mathrm{Bn}, \mathbf{7 a}\end{array}$

We have now extended our investigations to the synthesis and behavior of alkyl zirconium compounds of the type $\left[\mathrm{ZrR}\left(\eta^{5}-\mathrm{C}_{5} \mathrm{H}_{4} \mathrm{SiMe}_{2}-\eta^{1}-\mathrm{N}^{\mathrm{t}} \mathrm{Bu}\right)\left(\eta^{5}-\mathrm{C}_{5} \mathrm{H}_{4} \mathrm{R}^{\prime}\right)\right](\mathrm{R}=\mathrm{Me}, \mathrm{Bn}$; $\mathrm{R}^{\prime}=\mathrm{H}, \mathrm{SiMe}_{3}, \mathrm{SiMe}_{2} \mathrm{CH}_{2} \mathrm{CH}=\mathrm{CH}_{2}$ ). Previously reported chloro derivatives $\left[\mathrm{ZrCl}\left(\eta^{5}-\mathrm{C}_{5} \mathrm{H}_{4} \mathrm{SiMe}_{2}-\eta^{1}-\mathrm{N}^{\mathrm{t}} \mathrm{Bu}\right)\left(\eta^{5}-\mathrm{C}_{5} \mathrm{H}_{4} \mathrm{R}^{\prime}\right)\right]$ $\left(\mathrm{R}=\mathrm{H}(\mathbf{1}), \mathrm{SiMe}_{3} \text { (2), } \mathrm{SiMe}_{2} \mathrm{CH}_{2} \mathrm{CH}=\mathrm{CH}_{2}(3)\right)^{7}$ react with excess methyllithium, MeLi, or benzylmagnesium chloride, $\mathrm{BnMgCl}$, at room temperature to afford the corresponding alkyl derivatives $\left[\mathrm{ZrR}\left(\eta^{5}-\mathrm{C}_{5} \mathrm{H}_{4} \mathrm{SiMe}_{2}-\eta^{1}-\mathrm{N}^{\mathrm{t}} \mathrm{Bu}\right)\left(\eta^{5}-\mathrm{C}_{5} \mathrm{H}_{4} \mathrm{R}^{\prime}\right)\right]$ $\left(\mathrm{R}=\mathrm{Me}, \mathrm{R}^{\prime}=\mathrm{H}(\mathbf{4}), \mathrm{SiMe}_{3}(\mathbf{5}), \mathrm{SiMe}_{2} \mathrm{CH}_{2} \mathrm{CH}=\mathrm{CH}_{2}(\mathbf{6 a})\right.$; $\mathrm{R}=\mathrm{Bn}, \mathrm{R}^{\prime}=\mathrm{SiMe}_{2} \mathrm{CH}_{2} \mathrm{CH}=\mathrm{CH}_{2}(7 \mathbf{a}), \mathrm{R}={ }^{13} \mathrm{CH}_{3}, \mathrm{R}^{\prime}=$ $\mathrm{SiMe}_{2} \mathrm{CH}_{2} \mathrm{CH}=\mathrm{CH}_{2}\left(\mathbf{6 a}^{*}\right)$, Scheme 1), which have been isolated as solids in ca. $85-90 \%$ yields and fully characterized by ${ }^{1} \mathrm{H},{ }^{13} \mathrm{C}$, and ${ }^{29} \mathrm{Si}$ NMR spectroscopy and elemental analysis.

The pendant allyl unit of the alkyl derivatives $\mathbf{6 a}$ and $7 \mathbf{a}$ isomerizes under certain reaction conditions. When benzene$d_{6}$ solutions of $6 \mathbf{a}$ were heated to $120^{\circ} \mathrm{C}$, the ${ }^{1} \mathrm{H}$ NMR spectra showed, after 10 days, the clean formation of the trans-1propenyldimethylsilyl cyclopentadienyl compound [ZrMe$\left.\left(\eta^{5}-\mathrm{C}_{5} \mathrm{H}_{4} \mathrm{SiMe}_{2}-\eta^{1}-\mathrm{N}^{\mathrm{t}} \mathrm{Bu}\right)\left(\eta^{5}-\mathrm{C}_{5} \mathrm{H}_{4} \mathrm{SiMe}_{2} \mathrm{CH}=\mathrm{CHCH}_{3}\right)\right](\mathbf{6 b})$ (Scheme 2). Surprisingly, allyl isomerization of benzyl compound 7a takes place in similar reaction conditions, and detection of pure $\left[\mathrm{ZrBn}\left(\eta^{5}-\mathrm{C}_{5} \mathrm{H}_{4} \mathrm{SiMe}_{2}-\eta^{1}-\mathrm{N}^{\mathrm{t}} \mathrm{Bu}\right)\left(\eta^{5}-\mathrm{C}_{5} \mathrm{H}_{4} \mathrm{Si}-\right.\right.$ $\left.\left.\mathrm{Me}_{2} \mathrm{CH}=\mathrm{CHCH}_{3}\right)\right](7 \mathbf{b})$ was possible after heating benzene- $d_{6}$ solutions of $7 \mathbf{a}$ at $120{ }^{\circ} \mathrm{C}$ for ca. 14 days. When the reactions were carried out on a preparative scale, derivatives $6 \mathbf{b}$ and $7 \mathbf{b}$ were isolated after ca. $8-10$ days at $120^{\circ} \mathrm{C}$ as yellow solids in ca. $70 \%$ yield. The selective allyl- to trans-1-propenyldimethylsilylcyclopentadienyl isomerization of both complexes 6a and $7 \mathbf{a}$ was unambiguously determined from ${ }^{1} \mathrm{H},{ }^{13} \mathrm{C}$, and ${ }^{29} \mathrm{Si}$ NMR spectra of the final derivatives $\mathbf{6} \mathbf{b}$ and $\mathbf{7 b}$. Selected NMR data assigned to the pendant olefinic unit for the alkyl compounds $\mathbf{6 a}, \mathbf{6 b}, \mathbf{7 a}$, and $\mathbf{7 b}$ are shown in Table 1 .

Assuming a $\mathrm{M}-\mathrm{H}$ addition-elimination mechanism, ${ }^{9}$ transformation of $\mathbf{6 a}$ and $7 \mathbf{a}$ into $\mathbf{6 b}$ and $7 \mathbf{b}$, respectively, would involve consecutive insertion and $\beta$ - $\mathrm{H}$, -alkyl elimination reactions of the $\mathrm{Zr}-\mathrm{C}$ bond into the olefin unit, as shown in Scheme 3. In any case, $\beta$-methyl and, even less feasible, $\beta$-benzyl elimination processes are required as final steps of the reaction to produce compounds $\mathbf{6 b}$ and $7 \mathbf{b}$, respectively, from the starting alkyl derivatives $\mathbf{6 a}$ and $\mathbf{7 a}$.

To investigate the role of the alkyl ligand in these isomerization processes, we examined the thermal behavior of the

(9) (a) Harrod, J. F.; Chalk, A. J. J. Am. Chem. Soc. 1966, 88, (15), 3491-3497, and references therein. (b) Herrmann, W. A.; Prinz, M. Applied Homogeneous Catalysis with Organometallic Compounds, 2nd ed.; Wiley-VCH: Weinheim, 2002; Vol. 3, p 1119. (c) Otsuka, S.; Tani, K. Transition Metals for Organic Synthesis; Wiley-VCH: Weinheim, 1998; Vol. 1, p 147. (d) Parshall, G. W.; Ittel, S. D. Homogeneous Catalysis, 2nd ed.; John Wiley and Sons: New York, 1992; pp 12-24.
Scheme 2

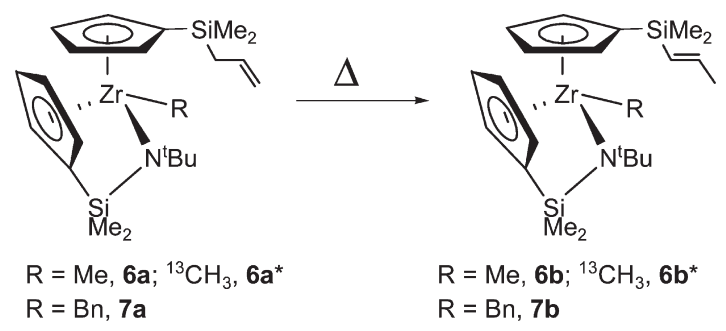

allyldimethylsilylcyclopentadienyl chloro derivative 3 . Unfortunately, compound $\mathbf{3}$ showed no isomerization of the allyl fragment under any of the conditions tested. ${ }^{10}$

In order to learn more about the pathways followed for the $\mathrm{M}$-alkyl ligand during the allyl isomerization, we decided to synthesize the labeled $\left[\mathrm{Zr}^{13} \mathrm{CH}_{3}\left(\eta^{5}-\mathrm{C}_{5} \mathrm{H}_{4} \mathrm{SiMe}_{2}-\eta^{1}-\mathrm{N}^{\mathrm{t}} \mathrm{Bu}\right)-\right.$ $\left.\left(\eta^{5}-\mathrm{C}_{5} \mathrm{H}_{4} \mathrm{SiMe}_{2} \mathrm{CH}_{2} \mathrm{CH}=\mathrm{CH}_{2}\right)\right]\left(\mathbf{6 a}^{*}\right)$. Upon heating the benzene- $d_{6}$ solutions of $6 \mathbf{a}^{*}$, the ${ }^{13} \mathrm{C}$ NMR spectra showed that trans- $\left[\mathrm{Zr}^{13} \mathrm{CH}_{3}\left(\eta^{5}-\mathrm{C}_{5} \mathrm{H}_{4} \mathrm{SiMe}_{2}-\eta^{1}-\mathrm{N}^{\mathrm{t}} \mathrm{Bu}\right)\left(\eta^{5}-\mathrm{C}_{5} \mathrm{H}_{4} \mathrm{SiMe}_{2} \mathrm{CH}=\right.\right.$ $\left.\left.\mathrm{CHCH}_{3}\right)\right]\left(\mathbf{b}^{*}\right)$ was cleanly formed after ca. 10 days. ${ }^{13} \mathrm{C}$ NMR analysis of the product showed no ${ }^{13} \mathrm{C}$ incorporation at any of the carbon resonances due to the pendant 1-propenyl unit, thus showing no evidence for insertion of the $\mathrm{Zr}-{ }^{13} \mathrm{CH}_{3}$ bond into the olefin fragment and/or $\beta-{ }^{13} \mathrm{CH}_{3}$ elimination processes. These experimental results suggest a different isomerization mechanism, in which no $\beta$ - $\mathrm{H}$, -alkyl elimination reaction takes place during the allyl to 1-propenyl transformation. In order to confirm the nonfeasibility of such a mechanism, we made a DFT computational study of the consecutive methyl and hydride insertion $/ \beta$-elimination steps on model system $\mathbf{6 a}$. The energy diagram of the complete reaction pathway for the allyl to 1-propenyl transformation involves six steps with six computationally located transition state structures (TS) and five intermediates, represented as compounds $\mathbf{A}-\mathbf{E}$ in Scheme 3. All calculated energy values are relative to $\mathbf{6 a}$, which was taken as the $H=0, G=0$ energy. ${ }^{11}$ The activation parameters for the first (TS6a-A; $\Delta H^{\ddagger}=57.6 \mathrm{kcal} / \mathrm{mol}, \Delta G^{\ddagger}=61.4 \mathrm{kcal} / \mathrm{mol}$ ) and the last step (TSE-6b; $\Delta H^{\ddagger}=48.8 \mathrm{kcal} / \mathrm{mol}, \Delta G^{\ddagger}=52.8 \mathrm{kcal} /$ mol), which involve $\mathrm{Zr}-\mathrm{CH}_{3}$ bond breaking or formation, respectively, are too high to be possible even at high temperatures. Conclusive disagreement between the theoretical results and the experimental observations also involves all of the intermediates $\mathbf{A}-\mathbf{E}$, which, with the exception of species $\mathbf{C}$, are more stable than the experimentally observed reaction product 1-propenyldimethylsilylcyclopentadienyl zirconium derivative $\mathbf{6 b}(\Delta H=-2.9 \mathrm{kcal} / \mathrm{mol}, \Delta G=-3.0 \mathrm{kcal} / \mathrm{mol})$. If such insertion/elimination pathways were operating, zirconacycle $\mathbf{A}$ $(\Delta H=-12.8 \mathrm{kcal} / \mathrm{mol}, \Delta G=-9.6 \mathrm{kcal} / \mathrm{mol})$ should be the only product of the reaction, as it is, by far, the most stable compound. However, $\mathbf{6 a}$ and $\mathbf{6 b}$ or $7 \mathbf{a}$ and $\mathbf{7 b}$ are the only compounds detected when monitoring the isomerization reactions in benzene- $d_{6}$ by ${ }^{1} \mathrm{H}$ and ${ }^{13} \mathrm{C}$ NMR, and neither $\mathrm{Zr}-\mathrm{H}$ nor zirconacycle species have been experimentally observed. All of these factors show that a $\mathrm{M}-\mathrm{H}$, -alkyl addition-elimination mechanism must be ruled out.

A second traditional mechanism for olefin isomerization is a metal-assisted 1,3-hydrogen shift. This process involves coordination of the olefin to the metal center followed by transfer of one allylic C-3 hydrogen to the metal, to give a

(10) Thermal evolution of compound $\mathbf{3}$ is currently under study. Preliminary results indicate that there is no isomerization of the pendant allyl fragment but a cyclopentadienyl desilylation process.

(11) See Supporting Information for details of DFT calculations. 
Table 1. Selected ${ }^{1} \mathrm{H},{ }^{13} \mathrm{C}$, and ${ }^{29} \mathrm{Si}$ NMR Data $\left(\delta\right.$ in ppm, ${ }^{\text {cis }} J$, ${ }^{\text {trans }} J$ in $\left.\mathrm{Hz}\right)$ of Compounds $6 \mathrm{a}, \mathrm{b}$ and $7 \mathrm{a}, \mathrm{b}$

\begin{tabular}{|c|c|c|c|c|c|c|c|c|}
\hline & \multirow[b]{2}{*}{ compd } & \multicolumn{3}{|c|}{$-\mathrm{SiCH}_{2}-\mathrm{CH}=\mathrm{CH}_{2}$} & \multirow[b]{2}{*}{ compd } & \multicolumn{3}{|c|}{$-\mathrm{SiCH}=\mathrm{CHCH}_{3}$} \\
\hline & & $\mathrm{Si}-\mathrm{CH}_{2}$ & $=\mathrm{CH}$ & $=\mathrm{CH}_{2}$ & & $\mathrm{Si}-\mathrm{CH}=$ & $=\mathrm{CH}-$ & $-\mathrm{CH}_{3}$ \\
\hline${ }^{1} \mathrm{H}$ & $6 a$ & 1.59 (d) & $\begin{array}{l}5.72(\mathrm{~m}) \\
\left({ }^{\text {trans }} J=16,{ }^{\text {cis }} J=10\right)\end{array}$ & $\begin{array}{l}4.90\left(\mathrm{~d},{ }^{\text {trans }} J=16\right) \\
4.92\left(\mathrm{~d},{ }^{c i s} J=10\right)\end{array}$ & 6b & $\begin{array}{l}5.79(\mathrm{dq}) \\
\left({ }^{\text {trans }} J=19\right)\end{array}$ & $\begin{array}{l}6.03(\mathrm{dq}) \\
\left.{ }^{\text {trans } J}=19\right)\end{array}$ & $1.70(\mathrm{dd})$ \\
\hline $\begin{array}{l}{ }^{13} \mathrm{C}^{b} \\
{ }^{29} \mathrm{Si}\end{array}$ & & $\begin{array}{l}26.3(-) \\
-7.6\end{array}$ & $135.5(+)$ & $114.4(-)$ & & $\begin{array}{l}131.0(+) \\
-16.2\end{array}$ & $144.3(+)$ & $23.3(+)$ \\
\hline${ }^{1} \mathrm{H}$ & $7 a$ & $1.56(\mathrm{~d})$ & $\begin{array}{l}5.66(\mathrm{~m}) \\
\left({ }^{\text {trans }} J=18,{ }^{\text {cis }} J=11\right)\end{array}$ & $\begin{array}{l}4.92\left(\mathrm{~d},{ }^{\text {cis }} J=11\right) \\
4.89\left(\mathrm{~d},{ }^{\text {trans }} J=18\right)\end{array}$ & $7 b$ & $\begin{array}{l}5.78(\mathrm{dq}) \\
\left({ }^{\text {trans } J}=18\right)\end{array}$ & $\begin{array}{l}6.01(\mathrm{dq}) \\
\left.{ }^{\text {trans }} J=18\right)\end{array}$ & $1.71(\mathrm{dd})$ \\
\hline $\begin{array}{l}{ }^{13} \mathrm{C}^{a} \\
{ }^{29} \mathrm{Si}\end{array}$ & & $\begin{array}{l}26.2(-) \\
-7.8\end{array}$ & $135.2(+)$ & $114.6(-)$ & & $\begin{array}{l}130.7(+) \\
-15.6\end{array}$ & $144.7(+)$ & $23.3(+)$ \\
\hline
\end{tabular}

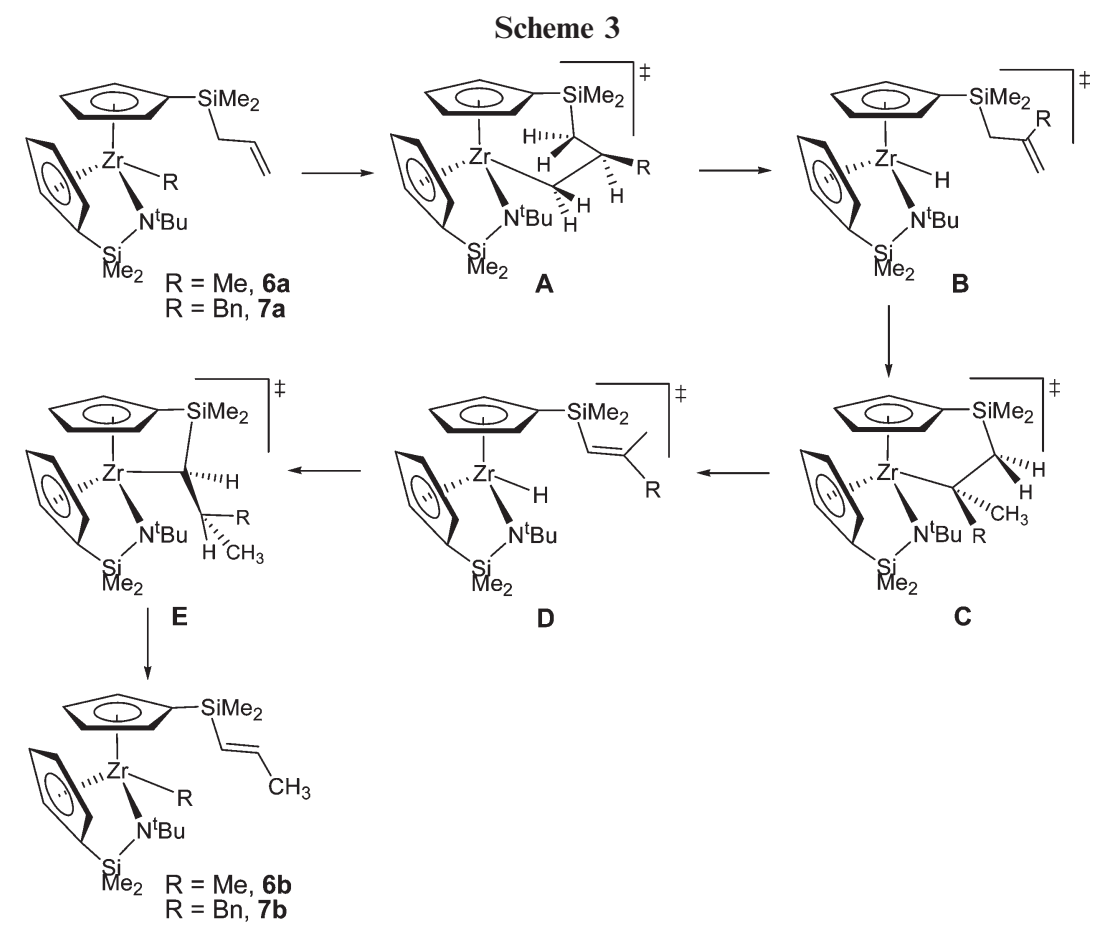

$\pi$-allyl-M-hydride intermediate. This hydride ligand migrates to the olefinic $\mathrm{C}-1$ to produce the allyl to 1-propenyl isomerization. For the zirconium system under study, one objection to this $\pi$-allylic mechanism is that the required net oxidative addition of a $\mathrm{C}-\mathrm{H}$ bond to a $\mathrm{Zr}(\mathrm{IV})$ metal center is not feasible.

Evidence of a $\mathrm{M}-\mathrm{N}$ insertion route operating in the intramolecular hydroamination/cyclization, IHC, of aminoalkenes mediated by neutral amido zirconium compounds has been found recently, ${ }^{12,13}$ and the viability of such a M-N insertion pathway in aminoallene IHC catalyzed by bis (amido) zirconium derivatives has been intensely studied by using the DFT method. ${ }^{14}$ Thus, an isomerization mechanism involving insertion of the $\mathrm{M}-\mathrm{N}$ bond into the pendant olefin present in derivatives 6a and 7a, shown in Scheme 4, should also be considered. Consistent with the strong $\mathrm{M}-\mathrm{N}$ bond,$^{12}$ the four-membered transition structure constituting the simultaneous $\mathrm{Zr}-\mathrm{N}, \mathrm{C}=\mathrm{C}$ bond cleavage and $\mathrm{Zr}-\mathrm{C}$, $\mathrm{C}-\mathrm{N}$ bond formation affords high calculated energy values

(12) Stubbert, B. D.; Marks, T. J. J. Am. Chem. Soc. 2007, 129 (19), 6149-6167.

(13) Majumder, S.; Odom, A. L. Organometallics 2008, 27 (6), 1174-1177.

(14) Tobisch, S. Chem.-Eur. J. 2008, 14 (28), 8590-8602.
Scheme 4

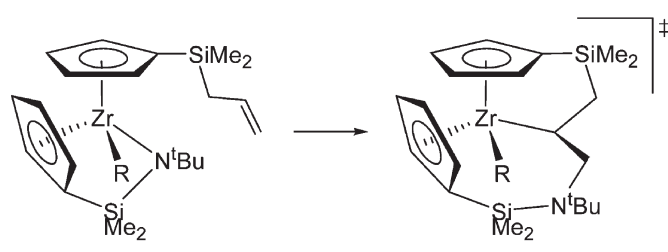

$6 a, 7 a$

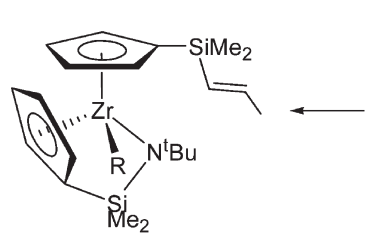

$6 b, 7 b$

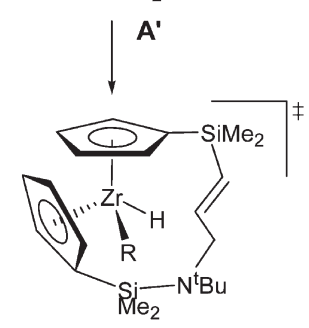

B'

$\left(\text { TS6a-A }^{\prime} ; \Delta H^{\ddagger}=51.3 \mathrm{kcal} / \mathrm{mol}, \Delta G^{\ddagger}=56.1 \mathrm{kcal} / \mathrm{mol}\right)^{15}$ from the DFT method.

(15) See Supporting Information for details of DFT calculations. 
Production of derivative $\mathbf{6 b}$ from the starting $\mathbf{6 a}$ through this $\mathrm{M}-\mathrm{N}$ insertion mechanism requires formation of a hydride-methyl $\mathrm{Zr}$ intermediate species $\mathbf{B}^{\prime}$, which contains a pendant olefin fragment close to the metal center. The evolution of such a species at the working temperatures of $120{ }^{\circ} \mathrm{C}$ is expected to follow favored reaction channels different from those required to afford the final $\mathbf{6 b}$ zirconium derivative. The hydrozirconation of such hydride-zirconium compounds with similar pendant alkene fragments has been demonstrated to be an easy process that is favored over double-bond isomerization. 5,7,16 Furthermore, analogous metallocene hydride-alkyl-zirconium species suffer thermal reductive elimination of alkane, ${ }^{17}$ which occur even without addition of any exogeneous ligands at temperatures of ca. $75^{\circ} \mathrm{C}$. These reasons, together with the calculated energies by the DFT method, led us to discount an isomerization mechanism involving olefin insertion into the $\mathrm{M}-\mathrm{N}$ bond.

Metal complexes with metal-oxygen and - nitrogen bonds facilitate $\mathrm{H}-\mathrm{H}$ and $\mathrm{C}-\mathrm{H}$ bond activation reactions. The positioning of a nucleophilic/basic heteroatom ligand (amido, alkoxo, imido, oxo, etc.) adjacent to a Lewis-acidic metal center provides opportunities for activation of organic substrates toward controlled bond-breaking and bondforming reactions. ${ }^{18}$ Weak $\mathrm{C}-\mathrm{H} \cdots \mathrm{X}$ interactions are claimed to be responsible for this kind of reactivity. ${ }^{19}$ As formation of M-hydride intermediate species can be rejected, we took into account these antecedents and considered the possibility that isomerization of derivatives $\mathbf{6 a}$ and $7 \mathbf{a}$ is initiated through an unusual $\mathrm{Zr}-\mathrm{N}$-assisted 1,3-allylic proton shift.

The proposed isomerization pathway would occur in two steps, shown in Figure 1. The first step consists of a net addition of a methylenic $\mathrm{C}-\mathrm{H}$ bond across the $\mathrm{Zr}-\mathrm{N}$ bond, via a four-membered transition structure (TS6a-F), in which $\mathrm{Zr}, \mathrm{N}, \mathrm{C}$, and $\mathrm{H}$ atoms are involved. The $\mathrm{Zr}-\mathrm{C}(1-3)$ bond distances (3.94, 5.18, $6.18 \AA$, respectively) found for TS6a-F agree well with a $\sigma$-allyl-Zr disposition. An intermediate $(\mathbf{F})$ of high energy, containing a secondary amine pendant ligand and a $\pi$-allyl- $\mathrm{Zr}$ bond, is formed. This disposition is energetically favored over a $\sigma$-allyl-Zr system. The following deprotonation of the amine group, which gives rise to the zirconium complex $\mathbf{6 b}$, takes place through a six-membered transition state (TSF-6b), with the three allylic C atoms, $\mathrm{Zr}$, $\mathrm{H}$, and $\mathrm{N}$ centers involved. A $\pi$-allyl- $\mathrm{Zr}$ representation for TSF-6b is upheld for the calculated $\mathrm{Zr}-\mathrm{C}(1-3)$ bond distances $(3.37,3.65,4.05 \AA$, respectively) of this transition state.

The activation energies of protonation and deprotonation steps are rather high, both over $40 \mathrm{kcal} / \mathrm{mol}$, but they agree well with the high reaction temperatures required experimentally. Most remarkably, the activation parameters of these pathways are more than $10 \mathrm{kcal} / \mathrm{mol}$ lower in energy

(16) Bazinet, P.; Tilley, T. D. Organometallics 2009, 2285-2293.

(17) (a) Baldwin, S. M.; Bercaw, J. E.; Brintzinger, H. H. J. Am. Chem. Soc. 2008, 130 (51), 17423-17433. (b) Pool, J. A.; Lobkovsky, E.; Chirik, P. J. J. Am. Chem. Soc. 2003, 125 (8), 2241-2251.

(18) (a) Abdur-Rashid, K.; Clapham, S. E.; Hadzovic, A.; Harvey, J. N.; Lough, A. J.; Morris, R. H. J. Am. Chem. Soc. 2002, 124 (50), 15104-15118. (b) Cundari, T. R.; Grimes, T. V.; Gunnoe, T. B. J. Am. Chem. Soc. 2007, 129 (43), 13172-13182. (c) Fulton, J. R.; Bouwkamp, M. W.; Bergman, R. G. J. Am. Chem. Soc. 2000, 122 (36), 8799-8800. (d) Hanna, T. E.; Lobkovsky, E.; Chirik, P. J. Eur. J. Inorg. Chem. 2007, No. 18, 2677-2685. (e) Hoyt, H. M.; Michael, F. E.; Bergman, R. G. J. Am. Chem. Soc. 2004, 126 (4), 1018-1019, and references therein.

(19) Calhorda, M. J. Chem. Commun. 2000, (10), 801-809, and references therein.

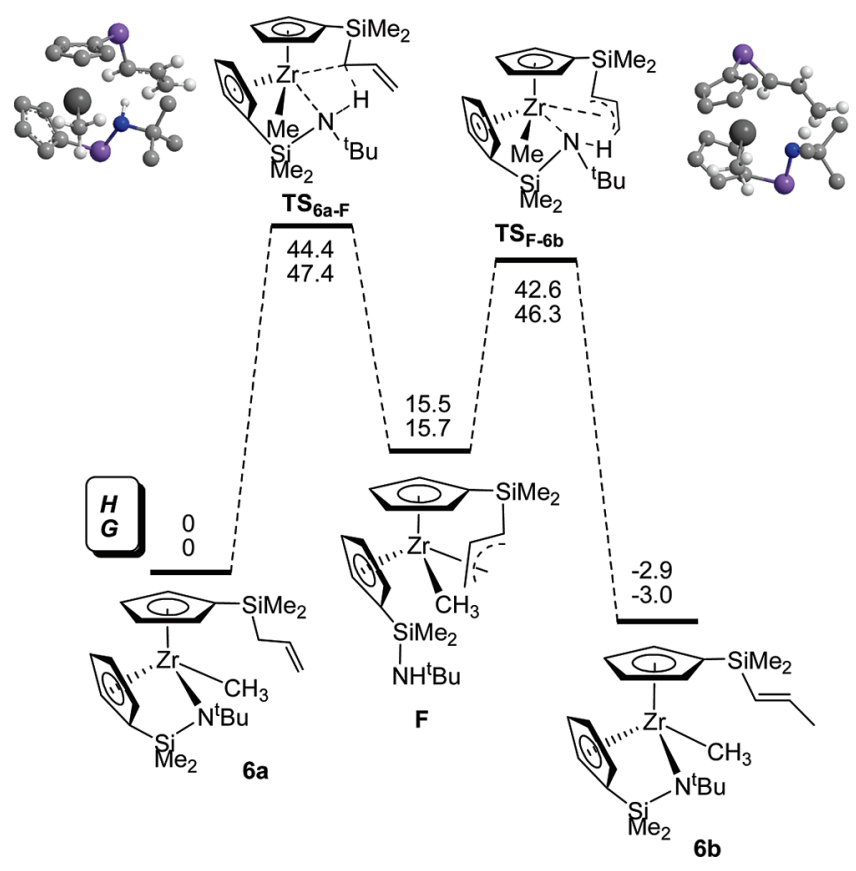

Figure 1. Energy diagram of the proposed pathway for the isomerization of $\mathbf{6} \mathbf{a}$ to $\mathbf{6} \mathbf{b}$ through a $\mathrm{N}$-assisted 1,3-allylic proton shift: $\Delta H$ and $\Delta G$, in $\mathrm{kcal} / \mathrm{mol}$.

than those calculated for the mechanisms involving insertion/elimination steps into $\mathrm{M}$-alkyl or $\mathrm{M}$-amido bonds. In agreement with the experimental results, the overall process is thermodynamically driven to the formation of the most stable compound, $\mathbf{6 b}(\Delta H=-2.9 \mathrm{kcal} / \mathrm{mol}, \Delta G=$ $-3.0 \mathrm{kcal} / \mathrm{mol}$ ). Finally, IRC calculations undoubtedly show the connection between the two transition state structures, TS6a-F and TSF-6b, and the cyclopentadienyl pendant olefin systems $\mathbf{6 a}$ and $\mathbf{6 b}$ through intermediate $\mathbf{F}$.

In summary, new monoalkyl zirconium compounds of the type $\left[\mathrm{ZrR}\left(\eta^{5}-\mathrm{C}_{5} \mathrm{H}_{4} \mathrm{SiMe}_{2}-\eta^{1}-\mathrm{N}^{\mathrm{t}} \mathrm{Bu}\right)\left(\eta^{5}-\mathrm{C}_{5} \mathrm{H}_{4} \mathrm{R}^{\prime}\right)\right]$ have been prepared and fully characterized. Allyldimethylsilylcyclopentadienyl derivatives $\left[\mathrm{ZrR}\left(\eta^{5}-\mathrm{C}_{5} \mathrm{H}_{4} \mathrm{SiMe}_{2}-\eta^{1}-\mathrm{N}^{\mathrm{t}} \mathrm{Bu}\right)\left(\eta^{5}-\right.\right.$ $\mathrm{C}_{5} \mathrm{H}_{4} \mathrm{SiMe}_{2} \mathrm{CH}_{2} \mathrm{CH}=\mathrm{CH}_{2}$ )] have been shown to undergo the intramolecular isomerization of the allyl fragment to cleanly afford the corresponding trans-1-propenyl $\left[\mathrm{ZrR}\left(\eta^{5}-\right.\right.$ $\left.\left.\mathrm{C}_{5} \mathrm{H}_{4} \mathrm{SiMe}_{2}-\eta^{1}-\mathrm{N}^{\mathrm{t}} \mathrm{Bu}\right)\left(\eta^{5}-\mathrm{C}_{5} \mathrm{H}_{4} \mathrm{SiMe}_{2} \mathrm{CH}=\mathrm{CHCH}_{3}\right)\right](\mathrm{R}=\mathrm{Me}$, $\mathrm{Bn})$ compounds. Whichever isomerization mechanism is responsible, selectivity to the trans-isomer formation is a consequence of the geometry imposed by the chelating character of the cyclopentadienyl-olefin ligand. On the basis of the experimental work and DFT computational studies reported here, an isomerization mechanism consisting of a 1,3-proton shift mediated by a noninnocent amide ligand is proposed.

\section{Experimental Section}

General Information. All manipulations involving syntheses of metal complexes and catalysis were performed at an argon/ vacuum manifold using standard Schlenk-line techniques under an argon atmosphere or in a glovebox MBraun MOD system. Solvents were dried by conventional procedures and freshly distilled prior to use. $\left[\mathrm{Zr}\left(\eta^{5}-\mathrm{C}_{5} \mathrm{H}_{4} \mathrm{SiMe}_{2}-\eta^{1}-\mathrm{N}^{\mathrm{t}} \mathrm{Bu}\right) \mathrm{Cl}_{2}\right],{ }^{20}[\mathrm{ZrCl}-$

(20) (a) Braun, L. F.; Dreier, T.; Christy, M.; Petersen, J. L. Inorg. Chem. 2004, 43 (13), 3976-3987. (b) Carpenetti, D. W.; Kloppenburg, L.; Kupec, J. T.; Petersen, J. L. Organometallics 1996, 15 (6), 15721581. 
$\left.\left(\eta^{5}-\mathrm{C}_{5} \mathrm{H}_{4} \mathrm{SiMe}_{2}-\eta^{1}-\mathrm{N}^{\mathrm{t}} \mathrm{Bu}\right)\left(\eta^{5}-\mathrm{C}_{5} \mathrm{H}_{4} \mathrm{R}^{\prime}\right)\right]^{7}\left(\mathrm{R}^{\prime}=\mathrm{H}, \mathrm{SiMe}_{3}, \mathrm{SiMe}_{2} \mathrm{CH}_{2^{-}}\right.$ $\left.\mathrm{CH}=\mathrm{CH}_{2}\right),{ }^{13} \mathrm{C}$-labeled methyllithium, ${ }^{13} \mathrm{CH}_{3} \mathrm{Li}^{21}$ and corresponding lithium salts of the substituted cyclopentadiene compounds, $\left[\left(\mathrm{C}_{5} \mathrm{H}_{4} \mathrm{R}^{\prime}\right) \mathrm{Li}\right]\left(\mathrm{R}^{\prime}=\mathrm{SiMe}_{3},{ }^{22} \mathrm{SiMe}_{2} \mathrm{CH}_{2} \mathrm{CH}=\mathrm{CH}_{2}{ }^{23}\right)$, were prepared according to previous reports. Diethyl ether $\left(\mathrm{Et}_{2} \mathrm{O}\right)$ solutions of MeLi and tetrahydrofuran (THF) solutions of $\mathrm{BnMgCl}$ were purchased from Aldrich. NMR spectra were recorded in a Bruker 400 Ultrashield. ${ }^{1} \mathrm{H}$ and ${ }^{13} \mathrm{C}$ chemical shifts are reported relative to tetramethylsilane. Coupling constants $J$ are given in $\mathrm{Hz}$. Elemental analyses were performed in our laboratories (UAH) on a Perkin-Elmer $2400 \mathrm{CHNS} / \mathrm{O}$ analyzer, Series II.

General Procedure for Preparation of $\left[\mathrm{ZrMe}\left(\eta^{5}-\mathrm{C}_{5} \mathrm{H}_{4} \mathrm{SiMe}_{2}-\right.\right.$ $\left.\left.\eta^{1}-\mathrm{N}^{\mathrm{t}} \mathrm{Bu}\right)\left(\boldsymbol{\eta}^{\mathbf{5}}-\mathrm{C}_{5} \mathrm{H}_{4} \mathrm{R}\right)\right]\left(\mathrm{R}=\mathrm{H}, \mathbf{4} ; \mathrm{SiMe}_{3}, \mathbf{5} ; \mathrm{SiMe}_{2} \mathrm{CH}_{2} \mathrm{CH}=\mathrm{CH}_{2}\right.$, 6a). A $1.5 \mathrm{M}$ solution of $\mathrm{MeLi}$ in $\mathrm{Et}_{2} \mathrm{O}(0.63 \mathrm{~mL}, 0.94 \mathrm{mmol})$ was added dropwise to an $\mathrm{Et}_{2} \mathrm{O}$ solution of $\mathbf{1}(0.24 \mathrm{~g}, 0.62 \mathrm{mmol}), \mathbf{2}$ $(0.21 \mathrm{~g}, 0.47 \mathrm{mmol})$, or $3(0.23 \mathrm{~g}, 0.47 \mathrm{mmol})$, respectively, and the reaction mixture was stirred for $12 \mathrm{~h}$ at room temperature. Solvent was completely removed from the resulting yellow suspension under vacuum, and the solid residue was extracted into hexane $(3 \times 5 \mathrm{~mL})$. Removal of the hexane from the yellow solution gave yellow to orange foams, which were identified as pure derivatives $\mathbf{4}, \mathbf{5}$, and $\mathbf{6 a}$, respectively, in isolated yields of $0.21 \mathrm{~g}$ of $4(91 \%), 0.19 \mathrm{~g}$ of $5(92 \%)$, and $0.18 \mathrm{~g}$ of $\mathbf{6 a}(88 \%)$. $\mathbf{6 a}$ : Anal. Calcd for $\mathrm{C}_{22} \mathrm{H}_{37} \mathrm{ZrNSi}_{2}$ : C, 57.08; H, 8.08; N, 3.03. Found: C, 56.70; H, 7.99; N, 2.90. ${ }^{1} \mathrm{H}$ NMR (plus HSQCGP, $\left.400 \mathrm{MHz}, \mathrm{C}_{6} \mathrm{D}_{6}\right): \delta 6.55,6.22,6.08,6.07,5.97,5.92,5.81,5.80$ (all m, each $\left.1 \mathrm{H}, \mathrm{C}_{5} \mathrm{H}_{4}\right), 5.72\left(\mathrm{~m}, 1 \mathrm{H},{ }^{\text {trans }} J_{\mathrm{HH}}=16,{ }^{\text {cis }} J_{\mathrm{HH}}=10\right.$, $\left.{ }^{3} J_{\mathrm{HH}}=8,=\mathrm{CH}\right), 4.92\left(\mathrm{~d}, 1 \mathrm{H},{ }^{\text {cis }} J_{\mathrm{HH}}=10,=\mathrm{CH}_{2}\right), 4.90(\mathrm{~d}, 1 \mathrm{H}$, $\left.\operatorname{trans}_{\mathrm{HH}}=16,=\mathrm{CH}_{2}\right), 1.59\left(\mathrm{~d}, 2 \mathrm{H},{ }^{3} J_{\mathrm{HH}}=8, \mathrm{Si}-\mathrm{CH}_{2}\right), 1.17(\mathrm{~s}, 9 \mathrm{H}$, $\left.\mathrm{C}\left(\mathrm{CH}_{3}\right)_{3}\right), 0.54,0.41,0.22,0.18$ (all s, each $\left.3 \mathrm{H}, \mathrm{Si}\left(\mathrm{CH}_{3}\right)_{2}\right), 0.11$ $\left(\mathrm{s}, 3 \mathrm{H}, \mathrm{Zr}-\mathrm{CH}_{3}\right) .{ }^{13} \mathrm{C}$ NMR (plus APT, plus HSQCGP, 100 $\left.\mathrm{MHz}, \mathrm{C}_{6} \mathrm{D}_{6}\right): \delta 135.5(+,=\mathrm{CH}), 124.5,120.7,117.5,116.2,115.3$, $114.7\left(\right.$ all,$\left.+ \mathrm{C}_{5} \mathrm{H}_{4}\right), 114.4\left(-,=\mathrm{CH}_{2}\right), 113.7\left(+, \mathrm{C}_{5} \mathrm{H}_{4}\right), 113.6$, $110.4\left(-\right.$, ipso- $\left.\mathrm{C}_{5} \mathrm{H}_{4}\right), 108.4\left(+, \mathrm{C}_{5} \mathrm{H}_{4}\right), 57.7\left(-, \mathrm{NC}\left(\mathrm{CH}_{3}\right)_{3}\right), 36.0$ $\left(+, \mathrm{C}\left(\mathrm{CH}_{3}\right)_{3}\right), 26.3\left(-,-\mathrm{CH}_{2}\right), 19.7\left(+, \mathrm{Zr}-\mathrm{CH}_{3}\right)$ 5.2, 2.9, -1.5, $-1.9\left(\mathrm{all}+, \mathrm{Si}-\left(\mathrm{CH}_{3}\right)_{2}\right) .{ }^{29} \mathrm{Si} \mathrm{HMBC} \mathrm{NMR}\left(79.4 \mathrm{MHz}, \mathrm{C}_{6} \mathrm{D}_{6}\right)$ : $\delta-25.2(\mathrm{Si}-\mathrm{N}),-7.6\left(\mathrm{Si}_{-} \mathrm{CH}_{2}\right)$.

Preparation of $\left[\mathrm{ZrBn}\left(\eta^{5}-\mathrm{C}_{5} \mathrm{H}_{4} \mathrm{SiMe}_{2}-\eta^{\mathbf{1}}-\mathrm{N}^{\mathrm{t}} \mathrm{Bu}\right)\left(\eta^{5}-\mathrm{C}_{5} \mathrm{H}_{4} \mathrm{Si}-\right.\right.$ $\left.\mathrm{Me}_{2} \mathrm{CH}_{2} \mathbf{C H}=\mathbf{C H}_{2}\right)$ ] (7a). A THF solution of $\mathrm{BnMgCl}(0.52 \mathrm{~mL}$, $1.06 \mathrm{mmol}$ ) was added at room temperature to a solution of 3 $(0.26 \mathrm{~g}, 0.53 \mathrm{mmol})$ in THF $(5 \mathrm{~mL})$. Stirring the reaction mixture for 3 days at $50{ }^{\circ} \mathrm{C}$ gave a yellow suspension. The solvent was removed under vacuum, hexane $(2 \times 3 \mathrm{~mL})$ was then added to the oily residue, the resulting suspension was filtered, and the yellow solution was dried under vacuum to produce a yellow oily residue, which was identified as pure derivative $7 \mathbf{a}$. Yield: $0.26 \mathrm{~g}$ (93\%). Anal. Calcd for $\mathrm{C}_{28} \mathrm{H}_{41} \mathrm{ZrNSi}_{2}$ : C, 62.39; H, 7.67; N, 2.60. Found: C, 62.25; H, 8.39; N 2.22. ${ }^{1} \mathrm{H}$ NMR (plus HSQCGP, $\left.400 \mathrm{MHz}, \mathrm{C}_{6} \mathrm{D}_{6}\right): \delta 7.28\left(\mathrm{dd}, 2 \mathrm{H},{ }^{3} J_{\mathrm{HH}}=8,{ }^{3} J_{\mathrm{HH}}=7, m-\mathrm{C}_{6} \mathrm{H}_{5}\right)$, $7.10\left(\mathrm{~d}, 2 \mathrm{H},{ }^{3} J_{\mathrm{HH}}=7, o-\mathrm{C}_{6} \mathrm{H}_{5}\right), 6.93\left(\mathrm{t}, 1 \mathrm{H},{ }^{3} J_{\mathrm{HH}}=8, p-\mathrm{C}_{6} \mathrm{H}_{5}\right), 6.28$, $6.12,6.05,6.02,5.86,5.79,5.77,5.74$ (all $\mathrm{m}$, each $\left.1 \mathrm{H}, \mathrm{C}_{5} \mathrm{H}_{4}\right), 5.66$ $\left(\mathrm{m}, 1 \mathrm{H},{ }^{\text {trans }} J_{\mathrm{HH}}=18,{ }^{\text {cis }} J_{\mathrm{HH}}=11,{ }^{3} J_{\mathrm{HH}}=8,=\mathrm{CH}\right), 4.92(\mathrm{~d}, 1 \mathrm{H}$, $\left.{ }^{\text {cis }} J_{\mathrm{HH}}=11,=\mathrm{CH}_{2}\right), 4.89\left(\mathrm{~d}, 1 \mathrm{H},{ }^{\text {trans }} J_{\mathrm{HH}}=18,=\mathrm{CH}_{2}\right), 2.50(\mathrm{~d}, 1 \mathrm{H}$, $\left.{ }^{2} J_{\mathrm{HH}}=10, \mathrm{PhCH}_{2}\right), 1.98\left(\mathrm{~d}, 1 \mathrm{H},{ }^{2} J_{\mathrm{HH}}=10, \mathrm{PhCH}_{2}\right), 1.56(\mathrm{~d}, 2 \mathrm{H}$, $\left.{ }^{3} J_{\mathrm{HH}}=8, \mathrm{Si}-\mathrm{CH}_{2}\right), 1.25\left(\mathrm{~s}, 9 \mathrm{H}, \mathrm{C}\left(\mathrm{CH}_{3}\right)_{3}\right), 0.44,0.36,0.21,0.19$ (all s, each $\left.3 \mathrm{H}, \mathrm{Si}\left(\mathrm{CH}_{3}\right)_{2}\right) .{ }^{13} \mathrm{C}$ NMR (plus APT, plus HSQCGP,

(21) Al-Humydi, A.; Garrison, J. C.; Youngs, W. J.; Collins, S. Organometallics 2005, 24 (7), 1784-1784.

(22) Cuenca, T.; Royo, P. Coord. Chem. Rev. 1999, 195, 447-498.

(23) Nicolas, P.; Royo, P.; Galakhov, M. V.; Blacque, O.; Jacobsen,

H.; Berke, H. Dalton Trans. 2004, No. 18, 2943-2951. $\left.100 \mathrm{MHz}, \mathrm{C}_{6} \mathrm{D}_{6}\right): \delta 155.9\left(-\right.$, ipso- $\left.\mathrm{C}_{6} \mathrm{H}_{5}\right), 135.2(+,=\mathrm{CH}), 129.0$ $\left(+, m-\mathrm{C}_{6} \mathrm{H}_{5}\right), 127.2\left(+, o-\mathrm{C}_{6} \mathrm{H}_{5}\right), 125.7\left(+, \mathrm{C}_{5} \mathrm{H}_{4}\right), 121.7\left(+, p-\mathrm{C}_{6} \mathrm{H}_{5}\right)$, $121.5,118.5,116.6,116.2,116.1,114.7$ (all,$\left.+ \mathrm{C}_{5} \mathrm{H}_{4}\right), 114.6$ $\left(-,=\mathrm{CH}_{2}\right), 113.4,111.4\left(-\right.$, ipso- $\left.\mathrm{C}_{5} \mathrm{H}_{4}\right), 109.6\left(+, \mathrm{C}_{5} \mathrm{H}_{4}\right), 58.6$ $\left(-, \mathrm{NC}\left(\mathrm{CH}_{3}\right)_{3}\right), 49.2\left(-,-\mathrm{CH}_{2} \mathrm{Ph}\right), 36.0\left(+, \mathrm{C}\left(\mathrm{CH}_{3}\right)_{3}\right), 26.2(-$, Si$\left.\mathrm{CH}_{2}\right), 4.9,2.9,-1.3,-1.9$ (all,$\left.+ \mathrm{Si}-\left(\mathrm{CH}_{3}\right)_{2}\right){ }^{29} \mathrm{Si} \mathrm{NMR}(79.4 \mathrm{MHz}$, $\left.\mathrm{C}_{6} \mathrm{D}_{6}\right): \delta-23.5(\mathrm{Si}-\mathrm{N}),-7.8\left(\mathrm{Si}-\mathrm{CH}_{2}\right)$.

Isomerization Reactions: Synthesis of $\left[\mathrm{ZrR}\left(\eta^{5}-\mathrm{C}_{5} \mathrm{H}_{4} \mathrm{SiMe}_{2}-\right.\right.$ $\left.\left.\eta^{1}-N^{t} \mathrm{Bu}\right)\left(\eta^{5}-\mathrm{C}_{5} \mathrm{H}_{4} \mathrm{SiMe}_{2} \mathrm{CH}=\mathrm{CHCH}_{3}\right)\right](\mathrm{R}=\mathrm{Me}, \mathbf{6 b} ; \mathrm{Bn}, 7 \mathrm{~b})$. A toluene $(3 \mathrm{~mL})$ solution of $6 \mathbf{6}(0.15 \mathrm{~g}, 0.32 \mathrm{mmol})$ or a THF $(3 \mathrm{~mL})$ solution of $7 \mathbf{a}(0.17 \mathrm{~g}, 0.37 \mathrm{mmol})$ was heated at $120^{\circ} \mathrm{C}$ for ca. 8 (6a) or 10 (7a) days. Solvent was completely removed from the resulting yellow to dark orange solutions, and the yellow solid residues were identified as pure derivatives $\mathbf{6 b}$ (yield: $0.10 \mathrm{~g}(69 \%))$ and $7 \mathbf{b}$ (yield: $0.12 \mathrm{~g}(71 \%))$. 6b: Anal. Calcd for $\mathrm{C}_{22} \mathrm{H}_{37} \mathrm{ZrNSi}_{2}$ : C, 57.08; H, 8.08; N, 3.03. Found: C, 56.82; H, 7.96; N 2.90. ${ }^{1} \mathrm{H}$ NMR (plus TOCSY, plus HSQCGP plus HMBCGP $\left.-{ }^{29} \mathrm{Si}, 400 \mathrm{MHz}, \mathrm{C}_{6} \mathrm{D}_{6}\right): \delta 6.58,6.20,6.17,6.16$ (all m, each $\left.1 \mathrm{H}, \mathrm{C}_{5} \mathrm{H}_{4}\right), 6.03\left(\mathrm{dq}, 1 \mathrm{H},{ }^{\text {trans }} J_{\mathrm{HH}}=19,{ }^{3} J_{\mathrm{HH}}=6\right.$, $=\mathrm{CH}-\mathrm{Me}), 5.95,5.93,5.87,5.86\left(\right.$ all $\mathrm{m}$, each $\left.1 \mathrm{H}, \mathrm{C}_{5} \mathrm{H}_{4}\right), 5.79$ (dq, $\left.{ }^{\text {trans }} J_{\mathrm{HH}}=19,{ }^{4} J_{\mathrm{HH}}=1,=\mathrm{CH}-\mathrm{Si}\right), 1.70\left(\mathrm{dd}, 3 \mathrm{H},{ }^{3} J_{\mathrm{HH}}=6\right.$, $\left.{ }^{4} J_{\mathrm{HH}}=1,=\mathrm{CCH}_{3}\right), 1.18\left(\mathrm{~s}, 9 \mathrm{H}, \mathrm{C}\left(\mathrm{CH}_{3}\right)_{3}\right), 0.55,0.43,0.29,0.28$ (all s, each $\left.3 \mathrm{H}, \mathrm{Si}\left(\mathrm{CH}_{3}\right)_{2}\right), 0.15\left(\mathrm{~s}, 3 \mathrm{H}, \mathrm{Zr}-\mathrm{CH}_{3}\right) .{ }^{13} \mathrm{C}$ NMR (plus APT, plus HSQCGP, $\left.100 \mathrm{MHz}, \mathrm{C}_{6} \mathrm{D}_{6}\right): \delta 144.3(+,=\mathrm{CHMe})$, $131.0(+,=$ CHSi $), 124.7,120.5,117.9,116.3,115.1,114.7,114.7$ $\left(\right.$ all,$\left.+ \mathrm{C}_{5} \mathrm{H}_{4}\right), 112.5\left(-\right.$, ipso- $\left.\mathrm{C}_{5} \mathrm{H}_{4}\right), 108.5\left(+, \mathrm{C}_{5} \mathrm{H}_{4}\right), 105.7$

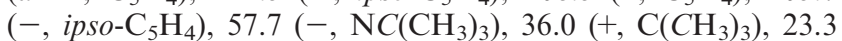
$\left(+,=\mathrm{CCH}_{3}\right), 19.5\left(+, \mathrm{Zr}-\mathrm{CH}_{3}\right), 5.2,2.9,-0.1,-0.5$ (all,+ Si$\left.\left(\mathrm{CH}_{3}\right)_{2}\right) .{ }^{29} \mathrm{Si}$ HMBC NMR $\left(\mathrm{C}_{6} \mathrm{D}_{6}\right): \delta-25.1(\mathrm{Si}-\mathrm{N}),-16.2$ $(\mathrm{Si}-\mathrm{CH}=)$. 7b: Anal. Calcd for $\mathrm{C}_{28} \mathrm{H}_{41} \mathrm{ZrNSi}_{2}$ : C, 62.39; H, 7.67; $\mathrm{N}, 2.60$. Found: C, 62.07; H, 7.30; N, 2.71. ${ }^{1} \mathrm{H}$ NMR (plus HSQCGP, $\left.400 \mathrm{MHz}, \mathrm{C}_{6} \mathrm{D}_{6}\right): \delta 7.29\left(\mathrm{dd}, 2 \mathrm{H},{ }^{3} J_{\mathrm{HH}}=8,{ }^{3} J_{\mathrm{HH}}=7\right.$, $\left.m-\mathrm{C}_{6} \mathrm{H}_{5}\right), 7.00\left(\mathrm{~d}, 2 \mathrm{H},{ }^{3} J_{\mathrm{HH}}=7, o-\mathrm{C}_{6} \mathrm{H}_{5}\right), 6.93\left(\mathrm{t}, 1 \mathrm{H},{ }^{3} J_{\mathrm{HH}}=8\right.$, $\left.p-\mathrm{C}_{6} \mathrm{H}_{5}\right), 6.35,6.15,6.05,6.05$ (all m, each $\left.1 \mathrm{H}, \mathrm{C}_{5} \mathrm{H}_{4}\right), 6.01(\mathrm{dq}$, $\left.1 \mathrm{H},{ }^{\text {trans }} J_{\mathrm{HH}}=18,{ }^{3} J_{\mathrm{HH}}=6,=\mathrm{CHMe}\right), 5.87,5.86,5.81,5.81$ (all $\mathrm{m}$, each $\left.1 \mathrm{H}, \mathrm{C}_{5} \mathrm{H}_{4}\right), 5.78\left(\mathrm{dq}, 1 \mathrm{H}\right.$, trans ${ }^{\mathrm{HH}}=18,{ }^{4} J_{\mathrm{H} H}=1$, $=\mathrm{CH}-\mathrm{Si}), 2.52\left(\mathrm{~d}, 1 \mathrm{H},{ }^{2} J_{\mathrm{HH}}=10, \mathrm{PhCH}_{2}\right), 2.01\left(\mathrm{~d}, 1 \mathrm{H},{ }^{2} J_{\mathrm{HH}}=\right.$ $\left.10, \mathrm{PhCH}_{2}\right), 1.71\left(\mathrm{dd}, 3 \mathrm{H},{ }^{3} J_{\mathrm{HH}}=6,{ }^{4} J_{\mathrm{HH}}=1,=\mathrm{CCH}_{3}\right), 1.26$ (s, 9H, C $\left.\left(\mathrm{CH}_{3}\right)_{3}\right), 0.45,0.38,0.28,0.26$ (all s, each $\left.3 \mathrm{H}, \mathrm{Si}\left(\mathrm{CH}_{3}\right)_{2}\right)$. ${ }^{13} \mathrm{C}$ NMR (plus APT, plus HSQCGP, $\left.100 \mathrm{MHz}, \mathrm{C}_{6} \mathrm{D}_{6}\right): \delta 156.0$ $\left(-\right.$, ipso- $\left.\mathrm{C}_{6} \mathrm{H}_{5}\right), 144.7$ (+, =CH-Me), 130.7 (+, =CH-Si), 129.0 $\left(+, m-\mathrm{C}_{6} \mathrm{H}_{5}\right), 127.2\left(+, o-\mathrm{C}_{6} \mathrm{H}_{5}\right), 125.7,121.7$ (both,$\left.+ \mathrm{C}_{5} \mathrm{H}_{4}\right)$, $121.5\left(+, p-\mathrm{C}_{6} \mathrm{H}_{5}\right), 118.7,116.8,116.2,116.1,115.0$ (all + , $\left.\mathrm{C}_{5} \mathrm{H}_{4}\right), 113.7,111.3$ (both -, ipso- $\left.\mathrm{C}_{5} \mathrm{H}_{4}\right), 109.8\left(+, \mathrm{C}_{5} \mathrm{H}_{4}\right), 58.5$ $\left(-, \mathrm{NC}\left(\mathrm{CH}_{3}\right)_{3}\right), 49.1\left(-,-\mathrm{CH}_{2} \mathrm{Ph}\right), 36.0\left(+, \mathrm{C}\left(\mathrm{CH}_{3}\right)_{3}\right), 23.3$ $\left(-,=\mathrm{C}-\mathrm{CH}_{3}\right), 4.9,2.9,-0.1,-0.3\left(\right.$ all,$\left.+ \mathrm{Si}-\left(\mathrm{CH}_{3}\right)_{2}\right) .{ }^{29} \mathrm{Si} \mathrm{NMR}$ $\left(79.4 \mathrm{MHz}, \mathrm{C}_{6} \mathrm{D}_{6}\right): \delta-23.5(\mathrm{Si}-\mathrm{N}),-15.6\left(\mathrm{Si}_{-}-\mathrm{CH}_{2}\right)$.

Acknowledgment. Financial support from the MEC of Spain (Project MAT2007-60997), from the CM (Project S-0505/PPQ/0328), and from the UAH (Project CCG08$\mathrm{UAH} / \mathrm{PPQ}-4026)$ is acknowledged. E.R. thanks the MEC for funding through RYC Program. C.E.P. acknowledges UAH for a fellowship. We also thank SGI/IZO-SGIker $\mathrm{UPV} / \mathrm{EHU}$ for allocation of computational resources.

Supporting Information Available: Details of synthetic procedures of ${ }^{13} \mathrm{C}$-labeled derivatives $\mathbf{6 a}^{*}$ and $\mathbf{6 b}^{*}$, full data characterization of compounds $\mathbf{4}, \mathbf{5}, \mathbf{6} \mathbf{a}^{*}$, and $\mathbf{6} \mathbf{b}^{*}$, selected NMR spectra, details of computational methods, and coordinates of DFT-optimized compounds. This material is available free of charge via the Internet at http://pubs.acs.org. 